\title{
Secondary ocular hypertension as a complication of posterior capsulotomy with Nd YAG laser in glaucoma suspect
}

\section{Hipertensión ocular secundaria a complicaciones por capsulotomía posterior con Nd YAG láser en sospechoso de glaucoma}

\author{
Abel Ramón-Concepción ${ }^{1 *}$, Karla G. Chávez-Gutiérrez², Ricardo D. Chávez-Gutiérrez², \\ Sergio Sital-Gastelum², Efraín Romo-Garcia ${ }^{2}$, Karina Ramos-Espinoza², Germán Villagomez-Tirado³, \\ Jesús R. Álvarez-Félix², Silvia Paz-Camacho ${ }^{1}$ and Yolanda Chavéz-Romero ${ }^{1}$ \\ ${ }^{1}$ Resident in Ophthalmology, Centro de Investigación y Docencia en Ciencias de la Salud; ${ }^{2} \mathrm{MD}$, Hospital Civil de Culiacán; ${ }^{3} \mathrm{MD}$, Hospital General \\ de Culiacán. Culiacán, Sin., Mexico
}

\begin{abstract}
Posterior capsulotomy is indicated when the visual acuity is committed so that impacts the performance of ordinary activities or exploring the posterior pole structures as in the evaluation of the retina or optic nerve is difficult. As expected is not free of complications. There are reports of intraocular lens (IOL) pitting, elevation of intraocular pressure (IOP), cystoid macular edema, retinal detachment, endophthalmitis, iritis, vitritis, corneal edema and macular holes. Multidisciplinary immediate management of complications of posterior capsulotomy Nd-YAG laser prevents loss of corneal clarity and diminishes or prevents optic neuropathy secondary to increased IOP. We report the case of 70-year-oldwoman who presents $48 \mathrm{~h}$ after performing posterior capsulotomy with Nd-YAG laser with ocular pain and IOP of $34 \mathrm{mmHg}$. The inicial management included topical and oral ocular hypotensive and inflammatory therapy achieving normal eye pressure. During slit lamp biomicroscopy we found microguttae in corneal endothelium, vitreous in the anterior chamber, IOL dislocation, retinal pigment epithelial detachment (RPED), subretinal fluid and corneal edema. A vitrectomy was performed. We decided conservative treatment of the IOL, close monitoring and treatment of IOP and specular microscopy as part of a comprehensive treatment. Finally, subretinal fluid reabsorption is achieved although RPED remains with no changes, we achieve resolution of corneal and IOP is $12 \mathrm{mmHg}$ without ocular antihypertensives. The final visual acuity is $20 / 40-2$.
\end{abstract}

Key words: Ocular hypertension. Capsulotomy. Nd YAG-Laser. Retinal pigment epithelial detachment.

\section{Resumen}

La realización de capsulotomía posterior está indicada cuando la agudeza visual está comprometida de tal forma que impacta en la realización de las actividades ordinarias o imposibilita la exploración de estructuras del polo posterior, como en la evaluación de la retina o del nervio óptico. Como es de suponer, no se encuentra libre de complicaciones. Dentro de las

Correspondence:

*Abel Ramón-Concepción

E-mail: dr.abel86@gmail.com
Available online: 01-03-2019

Date of reception: 28-09-2016

Date of acceptance: 11-01-2017

DOI: 10.24875/RMOE.M19000054
Rev Mex Oftalmol (Eng). 2019;93(2):83-88 www.rmo.com.mx

2604-1731/@ 2019 Sociedad Mexicana de Oftalmología. Published by Permanyer México SA de CV. This is an Open Access article under the CC BY-NC-ND license (http://creativecommons.org/licenses/by-nc-nd/4.0/). 
reportadas se encuentran: daño al lente intraocular, elevación de la presión intraocular (PIO), edema macular cistoide, desprendimiento de retina, endoftalmitis, iritis, vitritis, agujeros maculares y edema corneal. Presentamos el caso de un paciente de sexo femenino de 70 años que 48 h después de la realización de capsulotomía posterior con láser Nd-YAG acude con dolor ocular y PIO de $34 \mathrm{mmHg}$. Se inicia manejo tópico y oral con hipotensores oculares y antiinflamatorios, con lo que se logran presiones oculares normales. Se encuentran en la exploración otras complicaciones como microgutas en el endotelio corneal, vítreo en cámara anterior, subluxación de LIO, desprendimiento del epitelio pigmentado de la retina, líquido subretiniano y edema corneal. Se decide vitrectomía y manejo conservador del LIO, seguimiento estrecho de PIO y conteo endotelial. Se logra reabsorción del líquido subretiniano, resolución del edema corneal y PIO de $12 \mathrm{mmHg}$ sin hipotensores. La agudeza visual final es 20/40-2. El manejo multidisciplinario inmediato de las complicaciones de la capsulotomía posterior con láser Nd-YAG previene la pérdida de la transparencia de la córnea y disminuye o evita la neuropatía óptica secundaria al aumento de la PIO.

Palabras clave: Hipertensión ocular. YAG-Láser. Desprendimiento del epitelio pigmentado de la retina.

\section{Introduction}

Posterior capsule opacification is the most frequent cause of decreased visual acuity after cataract surgery and can occur in up to $25 \%$ of patients at 5 years 1 .

The mechanisms involved in its appearance are the type of intraocular lens (IOL) used, a small capsulorhexis, the type of IOL edge and posterior capsule polishing ${ }^{2,3}$.

Nd-YAG laser, for its acronym in English neodymium-doped yttrium aluminum garnet, is currently an excellent therapy in the management of posterior capsule opacification ${ }^{4,5}$.

It is a laser emission device with a wavelength of 1,064 nanometers $(\mathrm{nm})$ that can disintegrate ocular tissues and generate an optical breakdown with a short pulse of high power. This optical breakdown results in an ionization phenomena and plasma formation in the ocular tissue. This plasma formation causes acoustic and shock waves that promote tissue disintegration ${ }^{6,7}$.

Performing a posterior capsulotomy is indicated when visual acuity is reduced, affecting the performance of everyday activities or when it is impossible to explore the posterior pole structures like the retina or the optic nerve ${ }^{8,9}$.

As is to be expected, it is not free of complications. Among the reported are damage to the IOL, intraocular pressure (IOP) elevation, cystoid macular edema, retinal detachment, endophthalmitis, iritis, vitritis, macular holes and corneal edema.

IOP increase is the most frequent complication and it is usually transient. Elevations greater than 10 $\mathrm{mmHg}$ have been observed in $15-67 \%$ of the eyes. IOP increase is immediate, with a peak at 3-4 $\mathrm{h}$ that begins to decrease at $24 \mathrm{~h}$, although it can persist up to a week. Acute elevations can affect visual acuity. An association between major elevations and pre-existing glaucoma, capsulotomy size, sulcus or posterior chamber fixation of the IOL, myopia, retinal disease and cumulative energy has been reported. Some of the mechanisms described are the decrease in aqueous filtration by capsular debris, accumulation of inflammatory cells, liquefied vitreous and trabecular damage by shock waves. All patients with risk factors should be monitored closely and prescribed antihypertensive and anti-inflammatory prophylactic treatment.

Within the posterior segment complications, cystoid macular edema has been reported in $0.55-2.5 \%$ and may occur 3 to 11 months after the posterior capsulotomy. Retinal detachment has been reported in $0.08-3.6 \%$. It can occur immediately after the posterior capsulotomy or years later ${ }^{10}$.

Damage to the IOL occurs in $15-33 \%$. It is more frequent if the IOL is adhered to the posterior capsule or if the opacity is thick. The dotting or marks in the optics can cause glare and depends on the IOL material. The damage threshold is lower for silicone lenses, intermediate for PMMA and high for acrylic ${ }^{11}$.

One of the most feared and troublesome complications is endophthalmitis. Propionibacterium acnes has been reported as a causative agent. The mechanism is the creation of a pathway for the bacteria of the posterior capsule to the vitreous ${ }^{12}$.

\section{Results}

We present the case of a 70-year-old patient with a 8-year history of systemic arterial hypertension treated with captopril, with cataract surgery of the right eye (OD) 17 years ago and IOL removal 3 years later (the cause is unknown). He also has a history of cataract surgery in the left eye (OS) 3 years ago. 
He came 48 hours after a posterior capsulotomy with Nd-YAG laser, referring pain and conjunctival hyperemia in OS, and hemicranial headache and vagal symptoms.

On exploration we found a visual acuity (VA) on OD of counting fingers $30 \mathrm{~cm}{ }^{*} 20 / 400$, and on OS of 20/60 ${ }^{*} \mathrm{NI}$ (no improvement). In the OD, clear cornea with extracapsular extraction scars is observed, normal anterior chamber with gonioscopy 4-4-4-4, patent iridectomy at M11, round and central pupil, aphakia, vitreous syneresis, applied retina, healthy vasculature, macular drusen, excavation of $6 / 10$, pale optic nerve with temporal atrophy and an IOP of $12 \mathrm{mmHg}$.

The OS showed hyperemic bulbar conjunctiva ++, reactive pupil, edematous cornea, descemet striae, apparent endothelial micro blebs, reactive pupil, gonioscopy ISNT 4-4-4-4 with pigment ++, vitreous in the anterior chamber with corneal endothelial touch , trace cells, normal iris, IOL subluxation, applied retina, macular drusen and apparent elevation of the foveolar retina, pale optic nerve with excavation $7 / 10$, visible lamina cribrosa, peripapillary atrophy and IOP of 34 $\mathrm{mmHg}$.

Immediate management of IOP is initiated with oral acetazolamide as a single-dose $250 \mathrm{mg}$ tablet (Acetadiazol $^{\circledR}$, Laboratorios Grin), as well as one drop of brimonidine, timolol, dorzolamide as a single-dose (2 $\mathrm{mg}, 5 \mathrm{mg}, 20 \mathrm{mg} / \mathrm{mL}$ Krytantek Ofteno ${ }^{\circledR}$, Sophia) plus one drop of $1 \%$ prednisolone as a single-dose (Sophipren Ofteno $\left.^{\circledR}\right)$. For corneal edema, $5 \%$ sodium chloride $\left(5 \%\right.$ Hiperton $\left.^{\circledR}\right)$ and deflazacort $1 \mathrm{mg} / \mathrm{kg} /$ day (Calcort $^{\circledR} 30 \mathrm{mg}$, Sanofi) 2 tablets every $24 \mathrm{~h}$ are started. Appropriate IOP control is achieved at 8 $\mathrm{mmHg}$.

In the medical records there is a visit registered one month before, stating that the patient was sent to the glaucoma department due to suspicious optic disc excavations. A visual field was not completed due to an untreated anxiety disorder, so an OS capsulotomy is performed and a subsequent glaucoma optical coherence tomography (OCT) is requested to continue studying the patient. This visit describes the OS exploration with a clear cornea, anterior chamber without the presence of vitreous and macular drusen in the posterior pole. This led us to conclude that the findings in the current visit were highly suggestive of complications related to the posterior capsulotomy. The capsulotomy description reported 42 shots with a power of $2.4 \mathrm{~mJ}$ and a capsulotomy size of $5 \mathrm{~mm}$, obtaining a free visual axis.

OCT is performed finding a retinal pigment epithelial detachment (RPED) associated with subretinal fluid

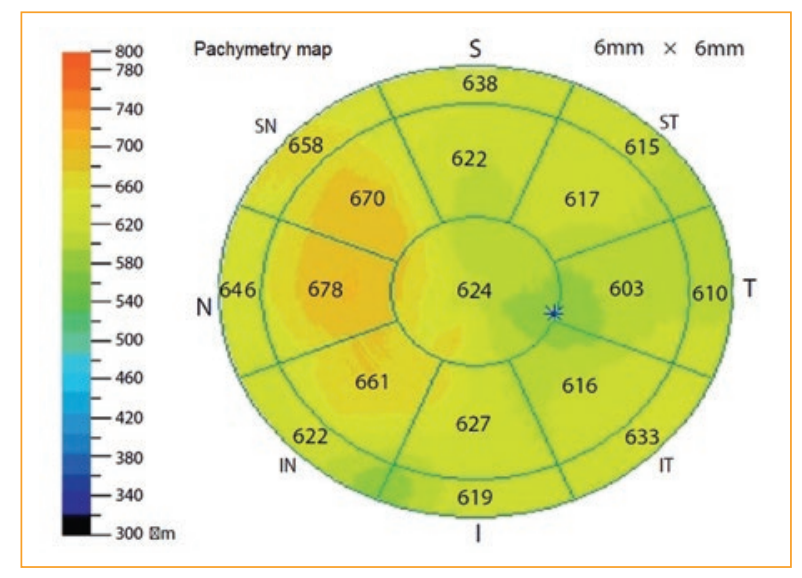

Figure 1. Corneal pachymetry, acute phase.

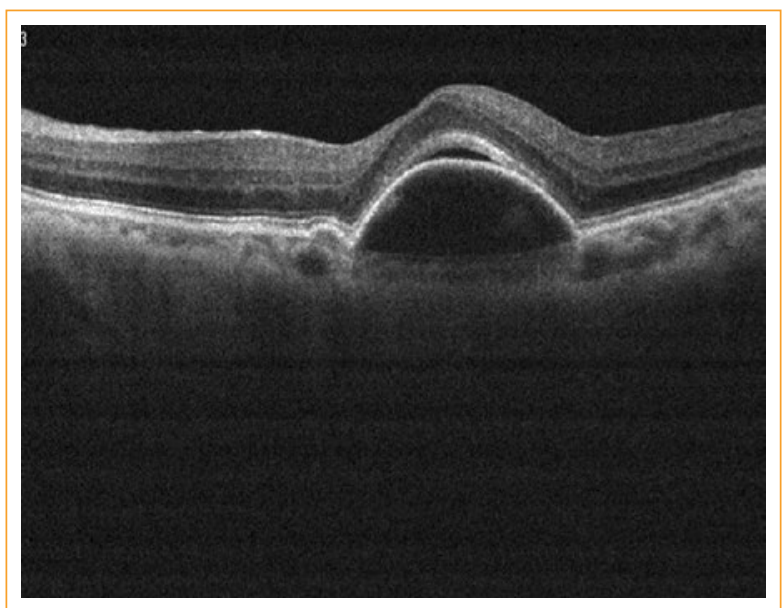

Figure 2. Retinal OCT, acute phase.

with a central macular thickness of $257 \mu$. Retinal nerve fiber layer (RNFL) average of 97.13 in OD and 122.49 in OS. Central pachymetry of $624 \mu$ (Fig. 1).

In the follow-up OCT, resolution of subretinal fluid with RPED persistence was observed (Figs. 2 y 3). Resolution of the corneal endothelial touch was observed (Figs. 4-6). The comparison of the RNFL during the phase of ocular hypertension and the follow-up at 3 days, at one week and at 3 months, showed an important thickening pattern in all the quadrants, except for the superior temporal and inferior temporal quadrants, which showed almost no increase (Fig. 7).

The corneal endothelium was analyzed, with an OD count of 1,578 cells $/ \mathrm{mm}^{2}$, hexagonality of $57 \%$; OS 1,263 cells $/ \mathrm{mm}^{2}$, hexagonality of $83 \%$.

We decided to perform a vitrectomy 4 months later (delayed for economic reasons), as well as adaptation of a scleral lens in the OD with aphakia and conservative 


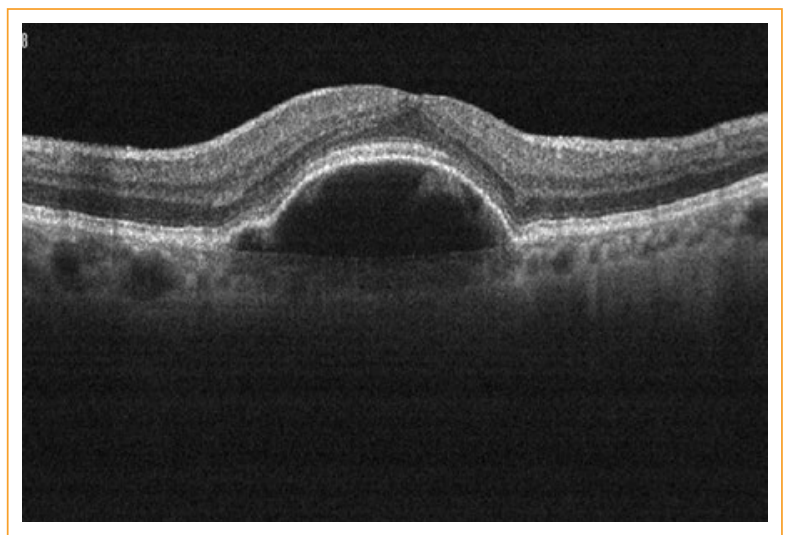

Figure 3. Retinal OCT, postoperative follow-up.

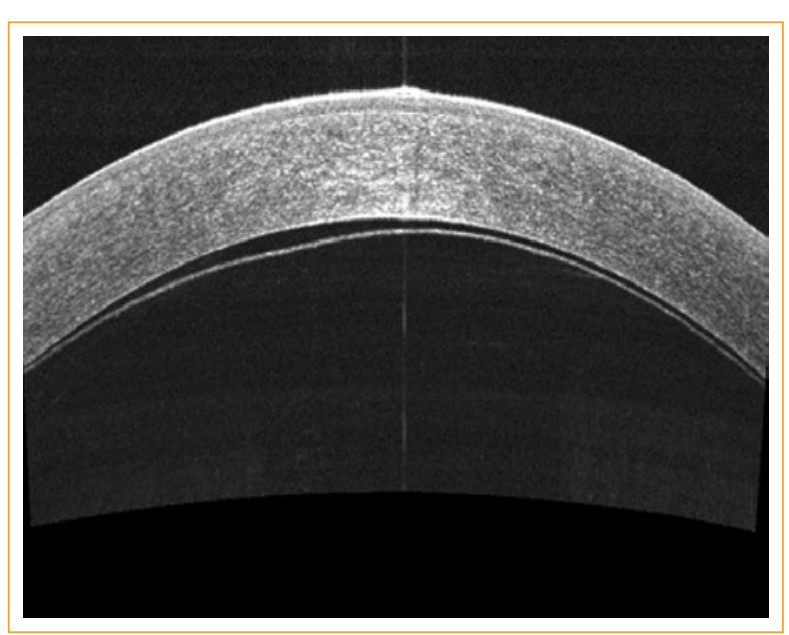

Figure 4. Corneal OCT, acute phase.

management of IOL subluxation. Eight months later, the patient had a pachymetry of $508 \mu$ (Fig. 8), with resolution of the subretinal fluid but with RPED persistence. The corrected visual acuity was $20 / 40^{-2}$ and IOP in OS was $12 \mathrm{mmHg}$ without antihypertensive or anti-inflammatory treatment.

\section{Discussion}

The potential mechanisms of increased IOP are inflammation secondary to the application of Nd-YAG laser, relative pupillary block due to $\mathrm{IOL}$ subluxation and vitreous prolapse into the anterior chamber, as well as angle closure from vitreous prolapse. A steroid-induced glaucoma cannot be ruled out, since the IOP increase and pain occurred 24 to $48 \mathrm{~h}$ after initiating prednisolone as a routine medication for capsulotomy, and a week

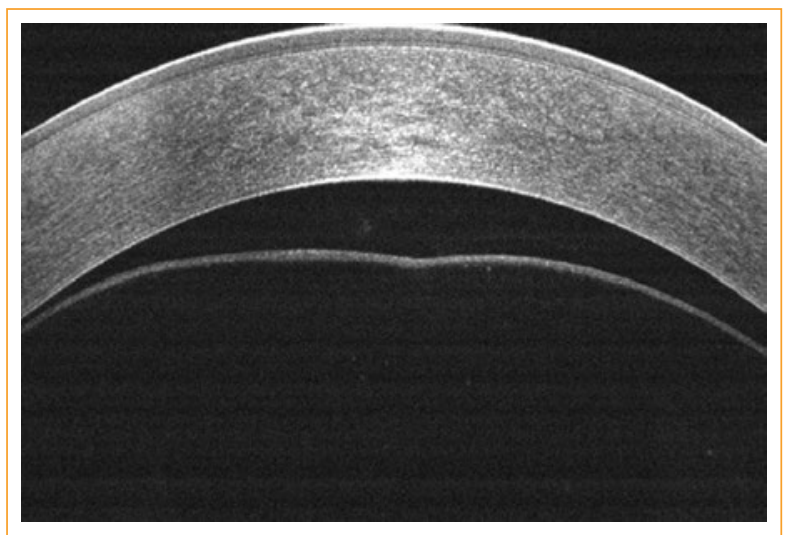

Figure 5. Corneal OCT at 7 days.

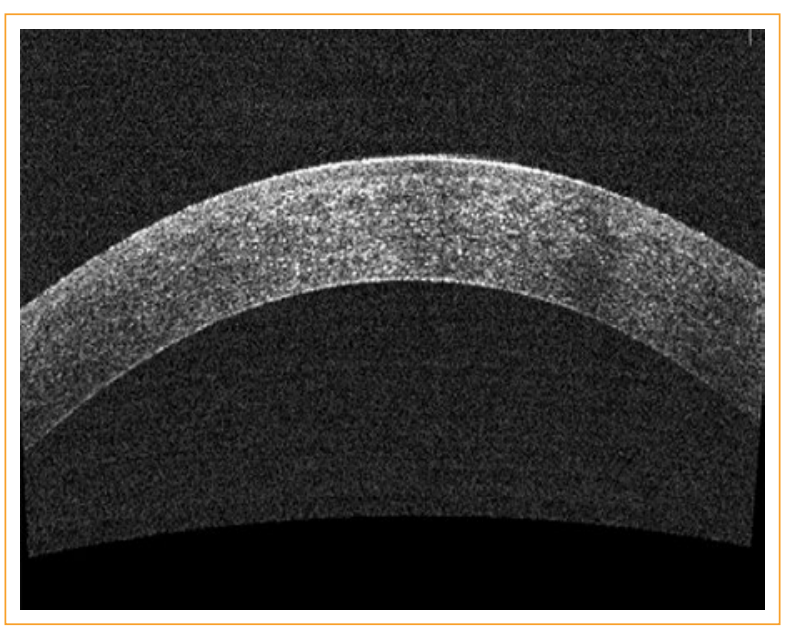

Figure 6. Retinal OCT, postoperative follow-up.

after its discontinuation there was an IOP decrease, even without hypotensive medications (Fig. 9).

Posterior pole complications such as RPED are less frequent, with only one case reported in a patient with age-related macular degeneration treated with antiangiogenic therapy ${ }^{13}$.

As a result of the analysis and follow-up of the RNFL (Fig. 8) the MARIAH Study was created based on the name of patient number 1 (María), and due to its acronym in English: «Measurement and Analysis of RNFL and IOP pattern during and after Acute angle-closure glaucoma and Hypertensive eyes", which aimed to 1) analyze the quadrants most sensitive to IOP increase, 2) search for a gradient that associates the $\mathrm{mmHg}$ increase with microns affectation in the RNFL and 3) compare the severity between the peak IOP and the number of days with elevated IOP. 


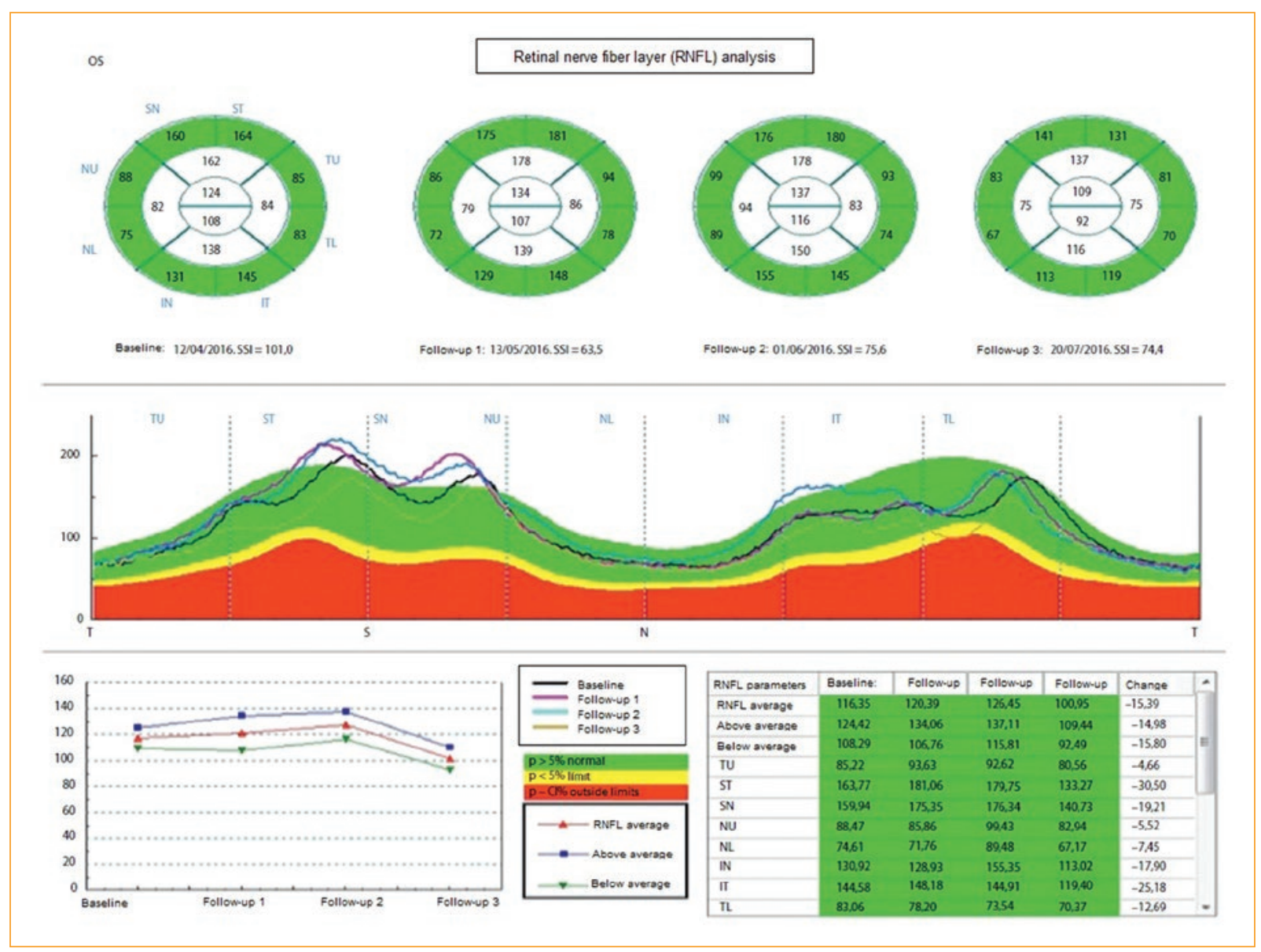

Figure 7. Analysis of the retinal nerve fiber layer.

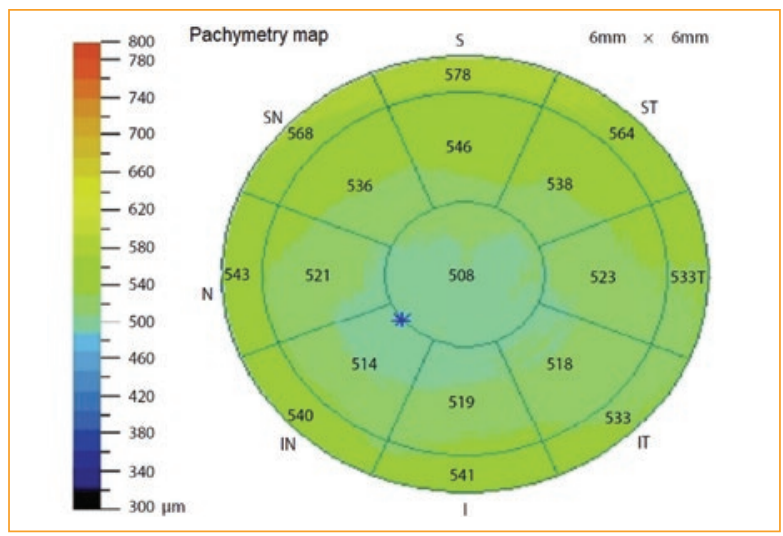

Figure 8. Corneal pachymetry, postoperative follow-up.

\section{Conclusion}

The immediate multidisciplinary management of the complications of posterior capsulotomy with Nd-YAG laser prevents the loss of transparency of the cornea and diminishes or avoids the optic neuropathy secondary to IOP increase.

\section{Ethical disclosures}

Protection of human and animal subjects. The authors declare that no experiments were performed on humans or animals for this study.

Confidentiality of data. The authors declare that they have followed the protocols of their work center on the publication of patient data.

Right to privacy and informed consent. The authors declare that no patient data appear in this article.

\section{Funding}

The authors received no specific funding for this work.

\section{Conflicts of interest}

The authors declare no conflicts of interest. 
Rev Mex Oftalmol (Eng). 2019;93

\section{IOP during treatment}

$\mathrm{mmHg} \quad 34$

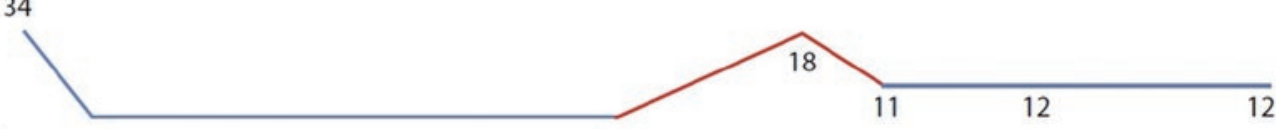

Acute phase

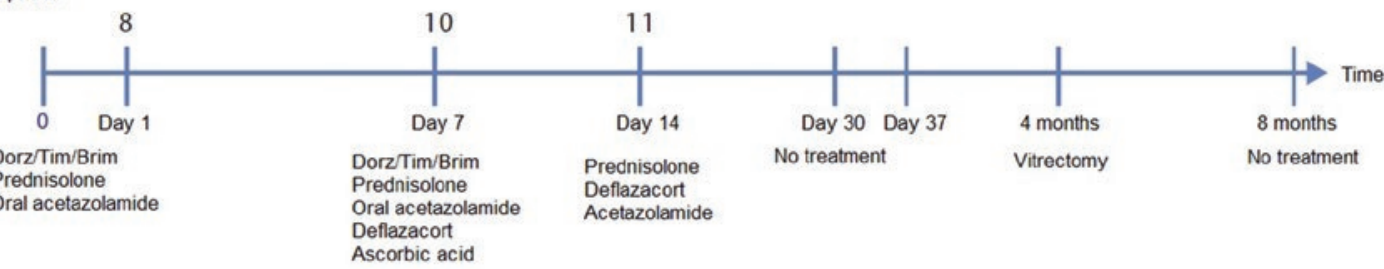

Dorz: Dorzolamide Tim: Timolol Brim: Brimonidine

Figure 9. IOP during treatment.

\section{References}

1. Schaumberg DA, Dana MR, Christen WG, Glynn RJ. A systemati coverview of the incidence of posterior capsule opacification. Ophthalmology. 1998;105:1213-21.

2. Chang A. Posterior capsule opacification 9 years after phacoemulsification with a hydrophobic and a hydrophilic intraocular lens. Eur J Ophthalmol. 2016 Jul 18.

3. Yotsukura E, Torii H. Effect of neodymium: YAG laser capsulotomy on visual function in patients with posterior capsule opacification and good visual acuity. J Cataract Refract Surg. 2016;42:399-404.

4. Wang MC, Woung LC. Digital retroilluminated photography to analyze posterior capsule opacification in eyes with intraocular lenses. J Cataract Refract Surg. 2000;26:56-61.

5. Aron-Rosa D, Aron JJ, Griesemann M, Thyzel R. Use of the neodymium-YAG laser to open the posterior capsule after len simplant surgery: A preliminary report. J Am Intraocul Implant Soc. 1980 $6: 352-4$
6. Steinert RF, Puliafito CA. The Nd:YAG laser in ophthalmology: Principles and clinical applications of photodisruption. Philadelphia; 1985.

7. Smith RT, Moscoso WE, Trokel S, Auran J. The barrier func-tion in neodymium-YAG laser capsulotomy. Arch Ophthalmol. 1995;113:645-52.

8. Cetinkaya S, Cetinkaya YF. The influence of size and shape of Nd: YAG capsulotomy on visual acuity and refraction. Arq Bras Oftalmol. 2015;78:220-3.

9. Hayashi K, Hayashi H, Nakao F, Hayashi F. Correlation between posterior capsule opacification and visual function before and after Neodymium YAG laser posterior capsulotomy. Am J Ophthalmol. 2003;136:720-6.

10. Winslow RL. Retinal complications following YAG laser capsulotomy. Ophthamology. 1985;92:785-9.

11. Khan B, Alam M. Complications of Nd:YAG laser capsulotomy. Pak J Ophthalmol. 2014;30.

12. Chaudhry M, Baisakhiya S. A rare complication of Nd-YAG capsulotomy: Propionibacterium acnes endopthalmitis. Nepal J Ophthalmol. 2011:3:80-2.

13. Vardarinos A. Tear of retinal pigment epithelium following YA Glaser posterior capsulotomy in a patient on anti-VEGF treatment for AMD: Six months' follow-up. Case Rep Ophthalmol. 2012;3:221-5. 